\title{
Quality indicators of roe deer (Capreolus capreolus L.) venison from two different Czech regions
}

\author{
Petr Dominik, Alena Saláková, Hana Buchtová, Ladislav Steinhauser \\ University of Veterinary and Pharmaceutical Sciences Brno, Faculty of Veterinary Hygiene and Ecology, \\ Department of Meat Hygiene and Technology, Brno, Czech Republic \\ Received October 16, 2012 \\ Accepted April 23, 2013
}

\begin{abstract}
This study focused on differences in the monitored quality indicators of roe deer venison depending on the region of the Czech Republic where roe deer are hunted. Quality of roe deer venison was evaluated based on $\mathrm{pH}$ values, colour (CIEL*a*b* system) and chemical composition (content of haem pigments, dry matter, pure protein, collagen and fat). Samples of muscle from the leg (m. gluteus medius) were taken from 22 female roe deer (Capreolus capreolus L.) from two hunting regions (Liberec and South Moravia) in the Czech Republic. In roe deer from Liberec, higher $\mathrm{pH}$ value $(5.65, P<0.001)$ was found; muscles were darker $\left(\mathrm{L}^{*}=36.03\right)$, contained higher redness $\left(\mathrm{a}^{*}=14.41, P<0.001\right)$ and yellowness values $\left(b^{*}=12.10\right)$ and higher chroma $\left(C^{*}=18.86\right)$. In roe deer from South Moravia, higher $(P<0.05)$ hue $\left(\mathrm{h}^{\circ}\right)$ values, and higher level of haem pigments $\left(2.45 \mathrm{mg} \cdot \mathrm{g}^{-1}\right)$ were found. Muscles from roe deer from South Moravia contained higher amounts of dry matter $(29.52 \%, P<0.001)$, pure protein $(23.84 \%$, $P<0.001)$ and total collagen $(0.86 \%)$, and lower amounts of intramuscular fat $(0.48 \%)$. These results may provide an important source of information for consumers of roe deer meat because several differences in the quality (chemical composition) of muscles from South Moravian region and Liberec region were found. Presumably, the differences between muscles from animals living in two different Czech regions were due to the diet, form of land use (more agricultural land in Southern Moravia, and forests and mountains in Liberec) and climatic conditions (Liberec lies in the northern part of the Czech Republic). It is the first study of this topic in the Czech Republic.
\end{abstract}

Muscle, female, $\mathrm{pH}$, colour, chemical indicators

Wild game meat has a low market share in economically developed countries. Traditionally, the largest game meat producers in Europe have been the Central European countries. Only a small portion of the meat from hunted animals is consumed by the hunters and their families, most of the meat from hunted animals is sold to meat processing plants (Daszkiewicz et al. 2012).

Roe deer (Capreolus capreolus L.) belongs among the most numerous feral large hoofed game species in the Czech Republic. Because of the long hunting season (16 May-30 September, and 1 September-31 December for males and females, respectively), roe deer meat is the most common venison in the Czech Republic. The roe deer population in the Czech Republic numbered 318271 animals by 31 March 2010, while the total number of hunted roe deer was 131873 , and the total weight of roe deer venison was 1978.1 tones (Czech Statistical Office 2012).

Consumers are increasingly concerned about the energetic and nutritional values of food, and appropriate diet as part of a healthy lifestyle, becoming increasingly interested in venison (Wiklund et al. 2010). Raw venison is valuable for its high levels of protein and low level of fat, which nutritionally favourable (Konjević 2008). It has low amounts of connective and adipose tissues. Venison has very species-specific aroma and taste characteristics (Belitz et al. 2009).

Colour is a very important criterion for consumers and depends among others on myoglobin concentration, the degree of myoglobin oxidation and on the meat structure (Ruiz de Huidobro et al. 2003). The contents of basic chemical components 
in venison depend primarily on the animal's age and sampling place (Rywotycki 2003).

The aim of the present study was to characterise selected chemical indicators, $\mathrm{pH}$ values and colour properties of muscle from the leg (m. gluteus medius) of roe deer venison depending on the hunting regions in the Czech Republic.

\section{Materials and Methods}

\section{Sample preparation}

Animals used in the experiment were wild game hunted in compliance with conditions established in the EC Regulation No. 853/2004. Samples for the study were obtained from 22 females of roe deer (Capreolus capreolus $\mathrm{L}$.) from two regions: Liberec $(\mathrm{n}=11)$ and South Moravia $(\mathrm{n}=11)$ of the Czech Republic. Samples were selected from roe deer carcasses delivered to a game processing facility in September 2009. The selection was based on similarity of age (average 3 years) and carcass weight after evisceration (average $10 \mathrm{~kg}$ ). The animals were shot (the shot wound was not contaminated with digestive tract contents), eviscerated within $24 \mathrm{~h}$, and passed as wholesome (Regulation EC No. 854/2004). The differences between the two different Czech regions were in the diet, form of land use (more agricultural land in Southern Moravia, forests and mountains in Liberec) and climatic conditions (Liberec lies in the northern part of the Czech Republic).

From each skinned roe deer carcass, muscle tissue samples weighing about $300 \mathrm{~g}$ were collected from the leg (m. gluteus medius). The samples collected were labelled, placed in plastic bags and maintained at a temperature below $7{ }^{\circ} \mathrm{C}$ until analysed. The quality indicators were measured after $72 \mathrm{~h}$ post mortem due to previous transportation of hunted deer, inspection for wholesomeness and safety, and venison sample collection.

$\mathrm{pH}$ value and colour measurement

The $\mathrm{pH}$ values were measured with a Double Pore needle probe (Hamilton Bonaduz AG, Switzerland) and a 340i WTW pH-meter (WTW, Germany), inserted into the muscle tissue. The colour of raw meat was measured three times by the CIEL*a*b* system using Konica Minolta CM 2600d (Konica Minolta, Japan). Measuring area of $8 \mathrm{~mm}$, illuminant D65 and $10^{\circ}$ standard observer were used. The instrument was standardised using a standard white plate. CIE L* - lightness, $\mathrm{a}^{*}$ - redness, $\mathrm{b}^{*}$ - yellowness, $\mathrm{C}^{*}-$ chroma and $\mathrm{h}^{\mathrm{o}}-$ hue were calculated using available software (Spectra Magic 3.61).

\section{Chemical analysis}

Samples of meat weighing about $150 \mathrm{~g}$ were homogenised for chemical analysis. The following variables were subsequently determined: amounts of dry matter $\left(103 \pm 2^{\circ} \mathrm{C}, 24 \mathrm{~h}\right)$ (International Standard 1997) and amount of intramuscular fat analysed on the Soxtec (FOSS Tecator AB, Sweden) with diethylether as the extraction agent. Samples were pre-dried $\left(135 \pm 1{ }^{\circ} \mathrm{C}, 3 \mathrm{~h}\right)$ before lipid extraction (Application Sub Note 31272001$)$. The pure protein content was determined as an amount of organically bound nitrogen by Kjeldahl method (conversion factor $f_{1}=6.25$ ) after precipitation with hot tannin solution using a Kjeltec 2300 (FOSS Analytical $\mathrm{AB}$, Sweden) semiautomatic analyser following the method recommended by the producer (Application Note 300 2003). The content of collagen was computed from the content of hydroxyproline amino acid (conversion factor $\mathrm{f}_{2}=8$ ). Hydroxyproline was determined quantitatively by photometric measurement of absorbance at $550 \mathrm{~nm}$ on a GENESYS ${ }^{\mathrm{TM}} 6$ spectrophotometer (Thermo Electron Corporation, USA). Haem pigment content was determined by the Hornsey method, with the absorbance being measured at $640 \mathrm{~nm}$ wavelength (Hornsey 1956; Izumimoto 1976).

\section{Data analysis}

Statistical data analyses were conducted using the STATISTICA $7 \mathrm{CZ}$ statistical program (StatSoft, Czech Republic). Statistical analyses were used for $\mathrm{m}$. gluteus medius depending on the hunting region. The significance of differences between samples was determined by the analysis of variance (ANOVA) using Tukey's test. The $P<0.05,0.01$ and 0.001 of significance were used.

\section{Results}

A comparison of venison (m. gluteus medius) from female roe deer from two regions showed higher $\mathrm{pH}$ values $(5.65, P<0.001)$ in roe deer from Liberec (Table 1). Muscles of roe deer from Liberec was darker (lower value $L^{*}=36.03$ ), and contained more redness $\left(\mathrm{a}^{*}=14.41\right)$ and yellowness $\left(\mathrm{b}^{*}=12.10\right)$. Significant difference $(P<0.001)$ was found for redness $\left(\mathrm{a}^{*}\right)$. Chroma values were also higher $\left(\mathrm{C}^{*}=18.86\right)$ in animals from Liberec, while higher $(P<0.05)$ hue $\left(\mathrm{h}^{\circ}\right)$ values were found in animals from South Moravia. Muscle of animals from South Moravia was found to contain more haem pigments $\left(2.45 \mathrm{mg} \cdot \mathrm{g}^{-1}\right)$ 
Table 1. ph, colour properties and content of haem pigments in muscle from the leg (musculus gluteus medius) of roe deer females.

\begin{tabular}{lccc}
\hline Indicators & \multicolumn{2}{c}{ Hunting region } & $\begin{array}{c}\mathrm{SR} \times \mathrm{LR} \\
(P \text { values }<)\end{array}$ \\
\hline $\mathrm{pH}$ & $5.50 \pm 0.05^{\mathrm{b}}$ & $5.65 \pm 0.09^{\mathrm{a}}$ & 0.001 \\
$\mathrm{~L}^{*}$ & $37.63 \pm 3.50^{\mathrm{a}}$ & $36.03 \pm 2.07^{\mathrm{a}}$ & $\mathrm{NS}$ \\
$\mathrm{a}^{*}$ & $11.42 \pm 0.89^{\mathrm{b}}$ & $14.41 \pm 2.21^{\mathrm{a}}$ & 0.001 \\
$\mathrm{~b}^{*}$ & $11.39 \pm 1.85^{\mathrm{a}}$ & $12.10 \pm 1.43^{\mathrm{a}}$ & $\mathrm{NS}$ \\
$\mathrm{C}^{*}$ & $16.17 \pm 1.76^{\mathrm{b}}$ & $18.86 \pm 2.30^{\mathrm{a}}$ & 0.01 \\
$\mathrm{~h}^{\text {o }}$ & $44.70 \pm 3.74^{\mathrm{a}}$ & $40.22 \pm 4.14^{\mathrm{b}}$ & 0.05 \\
$\mathrm{HP}\left(\mathrm{mg} \cdot \mathrm{g}^{-1}\right)$ & $2.45 \pm 1.00^{\mathrm{a}}$ & $1.94 \pm 0.52^{\mathrm{a}}$ & $\mathrm{NS}$ \\
\hline
\end{tabular}

Data are expressed as mean $\pm \mathrm{SD}, \mathrm{HP}-$ content of haem pigments, colour variables: $\mathrm{L}^{*}-$ lightness, $\mathrm{a}^{*}-$ redness, $b^{*}$ - yellowness, $C^{*}-$ chroma, $h^{\circ}-$ hue, $L R$ - Liberec region $(n=11), S R$ - South Moravia region $(n=11), S R \times$ LR - significant difference between the LR and SR regions, ${ }^{\mathrm{a}, \mathrm{b}}$ - means in the same row with different superscripts are significantly different $(P<0.001, P<0.01, P<0.05)$, NS - no significant differences $(P \geq 0.05)$.

(Table 1), however, it was lighter (higher $\mathrm{L}^{*}$ value), less red and yellow (lower $\mathrm{a}^{*}$ and $\mathrm{b}^{*}$ ) with lower chroma $\left(\mathrm{C}^{*}\right)$ value.

Evaluation of basic chemical properties showed that samples of muscle from animals from Southern Moravia contained more dry matter $(29.52 \%)$, more pure protein $(23.84 \%)$ and more total collagen $(0.86 \%)$ compared to muscle of animals from Liberec. The content of intramuscular fat in samples of muscle from Southern Moravia was lower $(0.48 \%)$ (Table 2). Significant differences $(P<0.001)$ were found comparing the contents of dry matter and pure proteins in animals from the two regions.

Table 2. Chemical properties of muscle from the leg (musculus gluteus medius) of roe deer females.

\begin{tabular}{lccc}
\hline Indicators & $\begin{array}{c}\text { Hunting region } \\
\text { South Moravia }\end{array}$ & Liberec & $\begin{array}{c}\text { SR } \times \text { LR } \\
(P \text { values }<)\end{array}$ \\
\hline Dry matter (\%) & $29.52 \pm 2.35^{\mathrm{a}}$ & $24.41 \pm 1.19^{\mathrm{b}}$ & 0.001 \\
Pure protein (\%) & $23.84 \pm 1.86^{\mathrm{a}}$ & $19.50 \pm 1.41^{\mathrm{b}}$ & 0.001 \\
Collagen (\%) & $0.86 \pm 0.33^{\mathrm{a}}$ & $0.74 \pm 0.29^{\mathrm{a}}$ & $\mathrm{NS}$ \\
Fat (\%) & $0.48 \pm 0.46^{\mathrm{a}}$ & $0.57 \pm 0.41^{\mathrm{a}}$ & $\mathrm{NS}$ \\
\hline
\end{tabular}

Data are expressed as mean $\pm S D, L R-$ Liberec region $(n=11), S R-$ South Moravia region $(n=11), S R \times L R-$ significant difference between the LR and SR regions, ${ }^{a, b}$ - means in the same row with different superscripts are significantly different $(P<0.001)$, NS - no significant differences $(P \geq 0.05)$.

\section{Discussion}

Meat quality, e.g. water binding capacity, keeping quality, tenderness, taste and colour is greatly influenced by meat $\mathrm{pH}$ (Pollard et al. 2002). Studies by Wiklund et al. (2000), Wiklund et al. (2001) and Pollard et al. (2002) showed that $\mathrm{pH}_{\text {ult }}$ of game that was hunted in a proper manner avoiding stress, and whose carcass was properly dressed and processed, was within the range of 5.5-5.75. Winkelmayer et al. (2004) reported pH in roe deer venison (m. longissimus) in dependence on the season of the year from 5.66 (spring) to 5.58 (autumn). Evaluating the effect of sex on the quality of roe deer venison, Daszkiewicz et al. (2012) found that $\mathrm{pH}_{\text {ult }}$ in $\mathrm{m}$. longissimus in males and females was 5.47 and 5.48, respectively. In our study, $\mathrm{pH}$ values were found within the above range, 
which testifies that slaughter was performed properly to avoid stress, and that the carcasses were properly handled.

Meat colour is important since it is subject to critical appraisal by the consumer and it is often the basis for product acceptability (Stevenson et al. 1989). The typical darkish red-and-brown colour of roe deer venison is generally explained by a higher content of myoglobin, which is necessary because the muscles are subject to a greater load associated with the free movement of animals in the wild (Ruiz de Huidobro et al. 2003). According to Hoffman et al. (2005), dark colour of venison is due to its low content of connective and adipose tissues. Daszkiewicz et al. (2012) focused on colour variables in m. longissimus dorsi from female roe deer $54 \mathrm{~h}$ post mortem and found the following values: $\mathrm{L}^{*}$ (lightness) $=32.61, \mathrm{a}^{*}($ redness $)=14.97, \mathrm{~b}^{*}($ yellowness $)=10.70, \mathrm{C}^{*}($ chroma $)=18.43$ and $\mathrm{h}^{\circ}($ hue $)=$ 35.44. The values obtained in our study were higher for $L^{*}, b^{*}$ and $h^{\circ}$ variables, but lower for $\mathrm{a}^{*}$ and $\mathrm{C}^{*}$ variables, i.e. our samples were lighter in colour and had higher values of yellowness and lower values of redness. Comparison of colour variables of muscle from roe deer females from the two regions showed that samples of muscle from animals from South Moravia were lighter in colour and had less redness.

Concentrations of haem pigments (myoglobin and haemoglobin) are influenced by the manner in which animals are slaughtered, and by their age. Harvested game is often insufficiently bled and a considerable amount of blood may remain in the game carcass. Myoglobin concentrations are also influenced by animal activity, because animals in the wild tend to move about more extensively (Wiklund et al. 2006). Haem pigments are an important source of iron for the human body (Young and West 2001). The content of haem pigments in roe deer venison was not available from foreign literature. For example, Wiklund et al. (2006) reported the concentration of haem pigment in $\mathrm{m}$. longissimus of red deer (Cervus elaphus) ranging from $7.74 \mathrm{mg} \cdot \mathrm{g}^{-1}$ to $7.27 \mathrm{mg} \cdot \mathrm{g}^{-1}$.

Chemical composition of venison may vary because it is influenced by many endogenous (animal species, age, sex, health status) and exogenous (living conditions, food availability and composition, season of the year) factors (Wiklund et al. 2010). According to Winkelmayer et al. (2004), roe deer venison on average contains $25.88 \%$ to $27.97 \%$ dry matter (m. longissimus). Studying the effect of sex on roe deer venison (m. longissimus dorsi), Daszkiewicz et al. (2012) found more dry matter in females $(26.20 \%)$ than in males $(24.68 \%)$. The dry matter content in muscle of the leg in our study was higher by about 5\% in animals from South Moravia. Winkelmayer et al. (2004) reported the protein content in roe deer venison (m. longissimus) in dependence on the season of the year $(22.48 \%$ and $22.77 \%$ in spring and autumn, respectively). Zomborszky et al. (1996) found $23 \%$ of proteins in both $\mathrm{m}$. semimembranosus and in $\mathrm{m}$. longissimus. More proteins in $\mathrm{m}$. longissimus dorsi in females $(22.79 \%)$ compared to males $(21.84 \%)$ were reported by Daszkiewicz et al. (2012). Collagen content also determines the nutritional value because it decreases the overall nutritional value of proteins (Taylor et al. 2002). Daszkiewicz et al. (2012) determined a collagen content of $0.364 \%$ and $0.360 \%$ in $\mathrm{m}$. longissimus dorsi in females and males, respectively. Values in our study were higher in both regions, which may have been due to the different type of muscle sampled. Roe deer venison ranks among foods with low energy value, which is due to its low fat content in muscle tissues (Mac Rae et al. 2005; Hoffman and Wiklund 2006). According to Zomborszky et al. (1996), the fat content in roe deer venison was $1.7 \%$ (m. longissimus). Daszkiewicz et al. (2012) found more fat in $\mathrm{m}$. longissimus dorsi of females $(1.46 \%)$ compared to males $(0.83 \%)$. Intramuscular fat values found in our study were lower, and the lowest fat content was found in samples from animals from South Moravia. Chemical composition of muscle (m. gluteus medius) samples from females of the two regions could have been affected by animal movements, diet composition, types of muscle other than those investigated in studies cited, and also the reproduction status of females (the young). 
This study showed differences in the monitored variables of roe deer venison within one sex depending on the region where roe deer were hunted. This particularly applies to variables that are related to post mortem biochemical processes such as $\mathrm{pH}$ and colour indicators that were monitored $72 \mathrm{~h}$ post mortem. A higher $\mathrm{pH}$ value was observed in female samples of the Liberec region. Muscle of animals from South Moravia was lighter and less red despite the fact that the content of haem pigments was higher. From the nutritional point of view, samples of muscle from animals from South Moravia were of better quality, with a higher pure protein content and lower intramuscular fat levels. Overall, it can be concluded that roe deer meat may, from the point of view of the quality indicators monitored, be a delicious and high quality food. This is the reason why venison remains a very specific product that is highly a valuable component of a balanced diet of the modern consumer due to its low content of intramuscular fat and a high content of protein.

\section{Acknowledgements}

This research was supported by the Ministry of Education, Youth and Sports of the Czech Republic, Grant No. MSM6215712402, Veterinary Aspects of Food Safety and Quality.

\section{References}

Application Note 300 2003: The determination of nitrogen according to Kjehldahl using block digestion and steam distillation. Foss Analytical AB Sweden, 1-12

Application Sub Note 3127 2001: Extraction of fat in meat and meat products. Foss Tecator AB Sweden, 1

Belitz HD, Grosch W, Schieberle P 2009: Food chemistry, Springer Berlin Heidelberg, p. 593, ISBN 978-3-54069933-0

Czech Statistical Office, Status and hunting of main game species (in Czech). Available at: http://vdb.czso.cz/ vdbvo/tabparam.jsp?cislotab=15-13\&vo=tabulka\&kapitola id=12\&voa=tabulka. Accessed August 28, 2012.

Daszkiewicz T, Kubiak D, Winarski R, Koba-Kowalczyk M 20̄12: The effect of gender on the quality of roe deer (Capreolus capreolus L.) meat. Small Rum Res 103: 169-175

Hoffman LC, Kritzinger B, Ferreira AV 2005: The effects of region and gender on the fatty acid, amino acid, mineral, myoglobin and collagen contents of impala (Aepyceros melampus) meat. Meat Sci 69: 551-558

Hoffman LC, Wiklund E 2006: Game and venison - meat for the modern consumer. Meat Sci 74: 197-208

Hornsey HC 1956: The colour of cooked cured pork. I.- Estimation of the nitric oxide-haem pigments. J Sci Food Agr 7: $534-540$

International Standard 1442 1997: Meat and meat products: Determination of moisture content (Reference method). Czech office for standards, metrology and testing, 1-4

Izumimoto M 1976: Direct method for assay of haem-pigment in muscle and its application. Nippon Nogeikagaku Kaishi. Japan Soc Biosci Biotech Agrochem 50: 55-59

Konjević D 2008: The roe deer (Capreolus capreolus) - from breeding to highly valuable food (In Croatian), Meso X: $81-85$

MacRae J, O'Reilly L, Morgan P 2005: Desirable characteristics of animal products from a human health perspective. Liv Prod Sci 94: 95-103

Pollard JC, Littlejohn RP, Asher GW, Pearse AJT, Stevenson-Barry JM, Mcgregor SK, Manley TR, Duncan SJ, Sutton CM, Pollock KL, Prescott J 2002: A comparison of biochemical and meat quality variables in red deer (Cervus elaphus) following either slaughter at pasture or killing at a deer slaughter plant. Meat Sci 60: 85-94

Regulation (EC) No 853/2004 of the European Parliament and of the Council of 29 April 2004 laying down specific hygiene rules for on the hygiene of foodstuffs. OJ L 139, 30.4.2004, 55-205

Regulation (EC) No 854/2004 of the European Parliament and of the Council of 29 April 2004 laying down specific rules for the organisation of official controls on products of animal origin intended for human consumption. OJ L 139, 30.4.2004, 206-320

Rywotycki R 2003: The influence of environment, mode of nutrition and animal species on level of nitrosamine contamination in venison. Meat Sci 65: 1045-1053

Ruiz de Huidobro F, Miguel E, Onega E, Blázquez B 2003: Changes in meat quality characteristics of bovine meat during the first 6 days post mortem. Meat Sci 65: 1439-1446

Stevenson JM, Seman DL, Weatherall IL, Littlejohn RP 1989: Evaluation of venison color by an objective method using CIELAB values. J Food Sci 54: 1661-1662

Taylor RG, Labas R, Smulders FJM, Wiklund E 2002: Ultrastructural changes during aging in M. longissimus thoracis from moose and reindeer. Meat Sci 60: 321-326

Wiklund E, Nilsson A, Ahman B 2000: Sensory meat quality, ultimate PH values, blood metabolites and carcass parameters in reindeer (Rangifer tarandus tarandus L.) fed various diets. Rangifer 20: 9-20 
Wiklund E, Dobbie P, Stuart A, Littlejohn RP 2010: Seasonal variation in red deer (Cervus elaphus) venison (M. longissimus dorsi) drip loss, calpain activity, colour and tenderness, Meat Sci 86: 720-727

Wiklund E, Sampels S, Manley TR, Pickova J, Littlejohn RP 2006: Effects of feeding regimen and chilled storage on water-holding capacity, colour stability, pigment content and oxidation in red deer (Cervus elaphus) meat. J Sci Food Agr 86: 98-106

Wiklund E, Stevenson-Barry JM, Duncan SJ, Littlejohn RP 2001: Electrical stimulation of red deer (Cervus elaphus) carcasses - effects on rate of $\mathrm{pH}$-decline, meat tenderness, colour stability and water - holding capacity. Meat Sci 59: 211-220

Winkelmayer R, Hofbauer P, Paulsen P 2004: A note on quality traits of the M. longisimus of roe deer (Capreolus capreolus) in Austrian sub-alpine regions. Fleischwirtschaft 10: $88-90$

Young O, West J 2001: Meat colour. In Meat Science and Applications (Hui YH, Nip WK, Rogers R, Young O, eds.), Marcel Dekker, New York, NY, 39-70

Zomborszky Z, Szentmihályi G, Sarudi I, Horn P, Szabó CS 1996: Nutrient composition of muscles in deer and boar. J Food Sci 61: 625-627 